\title{
REKONSTRUKSI STUDI ISLAM DI MASA KONTEMPORER
}

\section{RECONSTRUCTION OF ISLAMIC STUDY IN CONTEMPORARY TIMES}

\author{
Bani Syarif Maula \\ Institut Agama Islam Negeri (IAIN) Purwokerto \\ banisyarifm@iainpurwokerto.ac.id
}

\begin{abstract}
ABSTRAK
Studi agama, kususnya Islam, selalu memunculkan persoalan objektivitas antara peneliti dan objek yang dikaji sekaligus terhadap pihak lain, di mana masalah objektif atau subjektifnya suatu penelitian sangat bergantung terhadap pendekatan sekaligus metodologinya. Studi Islam bukan saja menyangkut persoalan fenomenologi, terutama jika dikaitkan dengan studi Islam di masa modern (kontemporer) sekarang ini. Studi Islam selalu dipengaruhi oleh perkembangan ilmu pengetahuan, sehingga pendekatan apapun yang digunakan untuk melakukan studi Islam, tidak dapat mendorong seseorang untuk cenderung mengukuhkan dan melahirkan truth claim terhadap pendekatannya dan menafikan yang lainnya. Selain itu, paradigma baru yang sesuai dengan perkembangan ilmu pengetahuan, khususnya ilmu-ilmu sosial, perlu mendapat tempat agar dapat menawarkan pandangan baru dalam mengkaji agama yang lebih terbuka dan berpandangan ke depan dengan mengakomodasi nilai-nilai universal.

Kata Kunci: Rekonstruksi, Studi Islam, Studi Agama, Kontemporer, Modern
\end{abstract}

\begin{abstract}
Religious studies, especially Islam, always raise questions of objectivity between researchers and the objects studied at the same time to other parties, where objective or subjective problems of a study depend heavily on the approach and methodology. Islamic studies are not only concerned with the issue of phenomenology, especially if it is associated with the study of Islam in the modern (contemporary) era. Islamic studies are always influenced by the development of science, so that any approach that is used to conduct Islamic studies, cannot encourage someone to tend to confirm and bring up the truth claim against his approach and deny the others. In addition, a new paradigm that is in line with the development of science, especially the social sciences, needs to be given a place so that it can offer a new view in studying religion that is more open and forward-looking by accommodating universal values.
\end{abstract}

Keywords: Reconstruction, Islamic Studies, Religious Studies, Contemporary, Modern

\section{PENDAHULUAN}

Studi Islam di masa

kontemporer banyak dipengaruhi oleh

faktor-faktor yang berasal dari luar

dunia akademik ilmiah, seperti politik dan ideologi, sehingga studi Islam lebih bersifat partikular dan tidak menggambarkan

fenomena

keagamaan yang sesungguhnya.

Bahkan lebih parah lagi, studi Islam 
semacam itu tidak diakui sebagai suatu karya ilmiah studi agama. Ketika Robert A. Segal menanyakan apa yang membuat studi agama (religious studies) dipandang sebagai sebuah disiplin ilmu pengetahuan, jawaban yang diberikan adalah bahwa kajian agama harus memiliki metode tersendiri (a distinctive method) yang oleh para pembela kajian agama klasik dimunculkan pendekatan fenomenologi sebagai metode tersendiri dalam penelitian agama; sehingga fenomenologi inilah yang menjadi ciri khas studi agama (phenomenology as the distinctive method of the discipline). ${ }^{1}$ Namun demikian, menurut Segal dengan mengutip Thomas Ryba, ${ }^{2}$ fenomenologi agama ternyata hanyalah sebuah penelitian tentang agama yang hanya menghimpun dan mengklasifikasikan data, sehingga fenomenologi agama berubah

1 Robert A. Segal, "Introduction", dalam Robert A. Segal, The Blackwell Companion to the Study of Religion (USA: Blackwell Publishing, 2006), hlm. xiii.

2 Menurut Thomas Ryba, fenomenologi adalah "scientific or analytic discourse about anything that appears subjectively and objectively to consciousness as pointing to something else; as such, it is about the very nature of those appearances but especially as they refer to or reveal an underlying, invariant structure or essence. Thomas Ryba, "Phenomenology of Religion", dalam Segal, The Blackwell, hlm. 93. menjadi taksonomi agama yang meng-kalisifikasikan agama menjadi keyakinan, praktek, dan benda-benda keagamaan; meskipun demikian, data-data tersebut tetap berguna bagi disiplin ilmu lain tentang kajian agama, misalnya antropologi agama, sosiologi agama, psikologi agama, dan lain-lain. ${ }^{3}$

Pembelaan kedua terhadap kajian agama sebagai sebuah disiplin ilmu pengetahuan adalah bahwa bidang kajian ini pada kenyataannya menjelaskan agama secara agamis (explaining religion "religiously") daripada secara antropologis, sosiologis, psikologis, dan lain-lain. Antropologi agama menjelaskan agama sebagai kasus budaya, sosiologi agama menjelaskan agama sebagai kasus dalam masyarakat, dan seterusnya. Namun, kajian agama (religious studies) menjelaskan agama bukan sebagai kasus apapun juga selain sebagai agama itu sendiri. ${ }^{4}$ Di sinilah letak persoalan ketika menjadikan agama sebagai bahan kajian, yaitu masalah objektivitas terhadap kajian dan keyakinan terhadap sakralitas agama. Di satu sisi

\footnotetext{
${ }^{3}$ Robert A. Segal, "Introduction", hlm. xiiixiv.

${ }^{4}$ Ibid., hlm. xiv.
} 
jika agama dijadikan sebagai objek kajian, berarti kajian tersebut mengharuskan adanya objektivitas antara peneliti dan objek yang dikaji sekaligus terhadap pihak lain, di mana masalah objektif atau subjektifnya suatu penelitian sangat bergantung terhadap pendekatan sekaligus metodologinya. Sedangkan di sisi lain, agama secara tradisional dipahami sebagai sesuatu yang suci, sakral dan agung, yang ketika hal-hal semacam agama dijadikan sebagai objek netral akan dianggap mereduksi atau bahkan merusak nilai tradisional agama secara normatif dan teologis. ${ }^{5}$

Sebagai bidang kajian ilmiah, penelitian agama bekerja dengan data yang mengandung makna-makna keagamaan dalam masyarakat atau individu pemeluknya. Karena itu kajian agama membutuhkan bantuan metodologis dari sudut pandang religionswissenchaft yang mengharuskan para pengkaji memperhatikan secara penuh apa yang dimaksud dengan "beragama" dan "agama" dalam masyarakat. Ia juga membutuhkan bantuan

5 M. Amin Abdullah, "Religion, Science and Culture: An Integrated, Interconnected Paradigm of Science", Al-Jami'ah: Journal of Islamic Studies, Vol. 52, No. 1, 2014, hlm. 175-203. metodologis dari sudut pandang studi agama untuk melihat makna keagamaan tertentu dari data yang menjadi concern seorang pemeluk agama dan kemudian menentukan bagaimana data tersebut diorganisir ke dalam suatu perangkat struktur dan sistem yang koheren. Hingga pada akhirnya usaha itu perlu dilanjutkan dengan menyusunnya kembali menjadi pola keagamaan yang bersifat umum, yang berlaku bagi setiap pemeluk agama yang hidup sekarang ini. ${ }^{6}$

Data-data keagamaan yang bersifat normatif-teologis ini pada saat yang sama mempunyai muatan historis, sosial, budaya, dan politik. Jadi dalam bentuknya yang historisempiris, agama selalu menjadi bagian dari setting historis dan sosial dari komunitasnya, namun pada saat yang bersamaan secara fenomenologis ia mempunyai pola umum (general pattern) yang dapat dipahami secara intuitif dan intelektual sekaligus oleh

6 M. Amin Abdullah, "Kata Pengantar", dalam Richard C. Martin (Ed), Kajian Islam dalam Studi Agama, terj. Zakiyuddin Baidhawy (Surakarta: Muhammadiyah University Press, 2001), hlm. iii. 
umat manusia di manapun mereka berada. $^{7}$

Di masa kontemporer sekarang ini, studi agama mengalami tantangan yang lebih banyak dibanding masamasa sebelumnya. Hal ini disebabkan karena fenomena agama, atau fenomena manusia dalam beragama, lebih dimotivasi oleh aspek-aspek yang sifatnya eksternal, seperti kepentingan politik, primordialisme, supremasi kelompok, dan lain sebagainya, dibanding faktor internal dari agama itu sendiri. Studi Islam dapat menjadi contoh dalam masalah ini, karena ia mempunyai tantangan berupa sikap kritis yang mulai memudar, terutama dalam kajian tentang ajaran Islam sendiri itu sendiri, yang sebenarnya itu merupakan pendapat sarjana muslim yang sangat beragam. Tantangan lain adalah berupa masalah objektivitas dalam studi Islam, yang berkaitan dengan persoalan perspektif insideroutsider para pengkaji Islam. Tantangan-tantangan tersebut memerlukan upaya rekonstruksi studi Islam dengan tanpa mengenyampingkan fenomena yang muncul di masa kontemporer ini,

\footnotetext{
${ }^{7}$ Ibid., hlm. iv.
}

yaitu antara lain adanya nilai-nilai yang dianggap universal seperti demokratisasi, hak asasi manusia dan kesetaraan gender; dan adanya gerakan salafisme di dunia Islam kontemporer.

\section{PEMBAHASAN}

\section{Persoalan Utama dalam Studi Islam}

\section{Sikap Kritis dalam Studi Islam}

Penelitian agama merupakan suatu usaha akademis yang menjadikan agama sebagai sasaran penelitian. Dalam kaitan ini, secara metodologis agama harus dijadikan sebagai suatu fenomena yang real, betapa pun mungkin terasa agama itu abstrak. Sebagai bidang kajian ilmiah, studi agama bekerja dengan data yang mengandung makna-makna keagamaan dalam masyarakat atau individu pemeluknya. ${ }^{8}$ Karena itu kajian agama membutuhkan bantuan metodologis yang mengharuskan para pengkaji memperhatikan secara penuh apa yang dimaksud dengan "beragama" dan "agama" dalam masyarakat. Aspek agama yang

8 M. Amin Abdullah, "Islamic Studies in Higher Education in Indonesia", Al-Jami'ah: Journal of Islamic Studies, Vol. 55, No. 2, 2017, hlm. 391-426. 


\section{Jurnal Yaqzhan : Analisis Filsafat, Agama dan Kemanusiaan|}

Vol 5, No 1, Juni 2019

bersifat normatif-teologis pada dasarnya juga mempunyai muatan historis, sosial, budaya, dan politik. Sehingga dalam bentuknya yang historis-empiris, agama selalu menjadi bagian dari setting historis dan sosial dari komunitasnya, namun pada saat yang bersamaan secara fenomenologis ia juga mempunyai pola umum (general patterns) yang dapat dipahami secara intuitif dan intelektual sekaligus oleh umat manusia di manapun mereka berada. ${ }^{9}$

Studi agama tersebut penting sebagai bagian dari upaya mengamati fenomena agama Islam dan pemelukpemeluknya. Apabila kita memperhatikan fenomena dalam masyarakat yang menyatakan diri mereka sebagai masyarakat beragama, maka kadang kita menjumpai realitas ironis yang menunjukkan betapa mudahnya mereka terperangkap dalam sikap absolutisme dan menganggap diri mereka sebagai pihak yang selalu merasa paling benar (claim of truth), sehingga dengan mudah menyalahkan dan melemparkan tuduhan murtad

${ }^{9}$ Shokhibul Mighfar, "Studi Agama Perspektif Insider-Outsider", Jurnal Lisan alHal, Vol. 4, No. 2, Desember 2012, hlm. 303329. atau kafir kepada pihak lain yang berseberangan pandangan dengan mereka. Cara beragama seperti itu jelas didasarkan pada belief (sesuatu yang diyakini kebenarannya) yang menjadi dasar bagi seseorang untuk bertindak, dan belief tersebut biasanya membentuk habits of mind yang melekat dalam benak seseorang sebagai sebuah cara pandang terhadap agama. $^{10}$

Kajian agama tidak hanya berhenti pada belief dan habits of mind saja, tetapi harus dimulai dari adanya doubt (keraguan). Terdapat dua macam doubt, yaitu genuine doubt (keraguan sejati) dan artificial doubt (keraguan semu). Hanya genuine doubt yang bisa mengantarkan seseorang pada tahapan berikutnya, yakni inquiry (penelitian). Pelaksanaan inquiry antara lain melalui metode tenacity (memegang teguh pendapat yang dianutnya secara masa bodoh tanpa mempertanyakannya lagi), authority (menanamkan keyakinan melalui otoritas institusi tertentu), a priori (mengikuti pendapat umum) dan

10 M. Amin Abdullah, "New Horizon of Islamic Studies through SocioCultural Hermeneutics", Al-Jami'ah: Journal of Islamic Studies, Vol. 41, No. 1, 2003, hlm. $1-24$. 
science (melakukan penelitian ilmiah). Melalui science inilah, pemikiran manusia akhirnya dapat mencapai makna hakiki (meaning) yang pada dasarnya lebih utama daripada 'kebenaran' (truth) karena 'makna' merupakan esensi dan substansi dari berbagai fenomena kehidupan manusia. ${ }^{11}$

\section{Objektivitas dalam Studi} Agama: Persoalan Perspektif

\section{Insider-Outsider}

Persoalan utama dalam studi agama adalah masalah perspektif insider dan outsider dalam mengkaji suatu agama, yaitu persoalan obyektifitas dan subjektifitas. ${ }^{12}$ Persoalan ini selalu menarik perhatian dalam kajian fenomena keagamaan masyarakat, karena antara peneliti dan obyek yang diteliti (masyarakat) mempunyai cara pandang dan pengalaman yang berbeda. Dengan demikain, yang menjadi pertanyaan dalam studi agama adalah bagaimanakah data-data keagamaan tersebut dapat dinilai objektif? Apakah pengkaji Islam dari kalangan

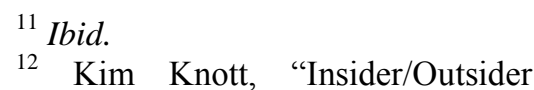

12 Kim Knott, "Insider/Outsider Perspectives", dalam John R. Hinnells (ed.), The Routledge Companion to the Study of Religion (New York: Routledge, 2005), hlm. 243-258. luar agama yang dikaji (outsider) mempunyai validitas data dari sudut pandang kalangan pemeluk agama tersebut (insider)? Apakah dari kalangan insider maupun outsider benar-benar menghasilkan penelitian yang objektif dan bisa dipertanggungjawabkan, karena latar belakang dan historisitas yang melekat erat pada insider dan outsider tersebut? Dalam hal ini Knot menyatakan sebagai berikut:

The contemporary form of the insider/outsider debate, which has focused on the limits and desirability of such an approach, has raised different issues. A number of critics have argued that the phenomenology of religion has been implicitly theological, even a spiritual technique in its own right. Its assumptions about the essential, fundamental and totalising nature of the sacred, and its frequent adoption of Christian categories and types for the theorisation of religion have been deemed to be problematic. Critics have questioned the rhetoric of impartiality and critical distance associated with phenomenology. ${ }^{13}$

Dua pendekatan kontemporer dalam studi agama muncul di dunia Barat dalam dekade terakhir ini, yaitu pendekatan sekuler dan saintifik

\footnotetext{
${ }^{13}$ Ibid., hlm. 245.
} 
Jurnal Yaqzhan : Analisis Filsafat, Agama dan Kemanusiaan|

Vol 5, No 1, Juni 2019

(secular and scientific) yang menilai obyektivitas dan bersikap sebagai outsider. Pendekatan ini muncul dari pandangan bahwa seseorang tidak bisa berasumsi terhadap sifat alami manusia yang tidak bisa diungkapkan — berdasarkan pada kategori-kategori tertentu seperti beragama dan pengalaman sakraltetapi seseorang bisa mengetahui sifat sosial dari agama. Pendekatan kedua terfokus pada refleksifitas (reflexivity), yang tidak mencari objektivitas tetapi ia menekankan pada aspek dialogis dari si peneliti terhadap objek penelitiannya. ${ }^{14}$

Isu seputar studi agama perlu diberi penguatan metodologis, yaitu melalui pendekatan fenomenologi agama. Tujuan yang mendasari pendekatan fenomenologis adalah untuk mengerti dengan penuh empati berdasarkan pada pengalaman insider, di samping kemampuan menahan diri dari penilaian negatif prejudice yang muncul dari outsider. ${ }^{15}$ Bercampurnya antara "agama" dan "sosio historis kultural" atau antara

\footnotetext{
${ }^{14}$ Ibid.

${ }^{15}$ Michael P. Ferber, "Critical Realism and Religion: Objectivity and the Insider/Outsider Problem", Annals of the Association of American Geographers, Vol. 96, No. 1 (Mar., 2006), hlm. 176-181.
}

yang sakral dan yang profan tidak mudah lagi dibedakan. Jika dalam wilayah keilmuan umum para ilmuwan masih bisa membuat pembedaan antara pure science yang bersifat inklusif dan applied science yang bersifat eksklusif lewat telaah filsafat keilmuan kontemporer, maka dalam wilayah keilmuan agama adalah sulit untuk membuat titik pemisah antara keduanya. Sebagaimana dinyatakan oleh Arkoun, unsur sakralitas (taqdīs alafkār al-dīniyyah) yang termuat dalam agama menambah rumitnya persoalan ini, karena seringkali didapati bahwa wilayah perbincangan keagamaan yang semula bersifat profan menjadi disakralkan. ${ }^{16}$

Upaya memahami agamaagama selalu berada dalam orbit kultur yang sangat beragam, sehingga persoalan krusial dalam studi agama adalah kuatnya keyakinan truth claim yang tidak terpisahkan dari kajian dan objek penelitian. Karena itulah, tentang "objektivitas" dalam studi agama Wilfred C. Smith menyatakan bahwa "No statement about a religion

\footnotetext{
${ }^{16}$ Sujiat Zubaidi Saleh, "Perspektif InsiderOutsider dalam Studi Agama: Membaca Gagasan Kim Knott", Jurnal Tsaqafah, Vol. 6, No. 2, Oktober 2010, hlm. 271-290.
} 
is valid unless it can be acknowledged by that religion's believers". 17

Sejatinya, kajian Islam dari para outsider memberi kontribusi gagasangagasan besar ilmiah yang memicu gerakan intelektual dalam peradaban Islam. Lahirnya daya kritis Islam terkadang lahir berkat kajian-kajian para outsider. Dengan cara berfikir kritis, intelektual Muslim mengetahui problem yang sedang dihadapi sembari mengusulkan pelbagai pemecahan yang harus segera dilakukan.

Berdasarkan pada uraian di atas, maka persoalan yang sangat krusial dan dilematis dalam studi agama adalah bagaimana seorang peneliti mampu menjaga objektivitas dan netralitas dalam melakukan kajian agama, baik sebagai insider maupun outsider. Cara pandang subjektif sering membawa seseorang untuk memilih cara beragama dengan truthclaim, sebagai konsekuensi adanya keimanan. $^{18}$

17 W. C. Smith, "Comparative Religion: Whither and Why?", dalam Mircea Eliade and J. M. Kitagawa (eds.), The History of Religions: Essays in Methodology (Chicago: The University of Chicago, 1959), hlm. 42.

18 Muhammad Abdul Rauf, "Outsiders' Interpretation of Islam" dalam Richard C. Martin (ed.) Approaches to Islam in Religious Studies (Oxford: Oneworld Publications, 2001), hlm. 185 .

\section{Rekonstruksi Studi Islam}

Tradisi ilmiah Islam kontemporer masih jauh tertinggal dan masih berkutat pada isu-isu internal umat Islam yang juga belum terselesaikan. Hal ini disebabkan karena umat Islam selalu menggunakan cara pandang yang sama (al-qirā'ah al-mutakarrirah) dalam melihat perubahan. ${ }^{19}$ Akibatnya, jika tradisi ilmiah kontemporer telah melangkah jauh dan berkembang sedemikian rupa, maka kondisi sebaliknya terjadi dalam tradisi akademik yang dikembangkan oleh para ilmuan Islam yang nampaknya justru masih didominasi oleh pendekatan positivistik dan bahkan secara tidak sadar sedang memperkuat motode ilmiah yang sudah mulai digugat oleh banyak kalangan. Kajian-kajian keislaman justru hanya terfokus pada isi atau substansi tanpa mempersiapkan kerangka kerja dan bangunan epistemologis yang menggantikan paradigm positivistik.

Tugas dan proyek besar keilmuan keislaman kontemporer

\footnotetext{
${ }^{19}$ M. Amin Abdullah, "Pengantar", dalam Jasser Auda, Membumikan Hukum Islam Melalui Maqasid Syariah, terj. Rosidin dan 'Ali 'Abd el-Mun'im (Bandung: Mizan, 2008), hlm. 9-16.
} 
Jurnal Yaqzhan : Analisis Filsafat, Agama dan Kemanusiaan|

Vol 5, No 1, Juni 2019

adalah bagaimana menjelaskan polapola keterhubungan antara khazanah keilmuan Islam (fiqih, tasawuf, kalam, dan lain-lain) dengan khazanah keilmuan modernkontemporer (ilmu-ilmu sosialhumaniora modern) dan mendamaikan silang pendapat yang tidak proporsional serta menghilangkan sikap saling curiga antara keduanya. Dalam melakukan tugas dan proyek tersebut, para tokoh muslim kontemporer berusaha menawarkan metodologinya masingmasing. Tawaran metodologi baru ini tidak seperti metodologi ulama klasik yang terlalu mencurahkan perhatian pada interpretasi literal terhadap alQur'an dan Sunnah. Metodologi baru tersebut menekankan hubungan dilalektis antara perintah-perintah teks wahyu dan realitas dunia modern. Pendekatan yang digunakan adalah memahami wahyu baik dari sisi teks maupun konteksnya. Hubungan antara teks wahyu dan masyarakat modern tidak dibangun melalui interpretasi literalis, melainkan melalui interpretasi terhadap ruh dan pesan universal yang dikandung teks wahyu. Di antara tokoh-tokoh pemikir Muslim kontemporer adalah Mahmoud Muhammad Thaha, Abdullahi Ahmed an-Na'im, Mohammed Arkoun, Fazlur Rahman, Khaleed Abou Fadl, Nasr Hamid Abu Zayd, Jasser Auda, dan lain-lain.

Mohammed Arkoun, misalnya, mendorong umat Islam agar meninggalkan episteme abad pertengahan yang menurutnya cenderung melupakan dimensi historisitas (tārīkhiyyah). Bagi Arkoun, epistemologi pemikiran Islam klasik cenderung bersifat tekstual-normatif yang sudah barang tentu sangat sulit mengadopsi berbagai perubahan sosial termasuk di dalamnya masalah perkembangan sains dan budaya.

\section{Pemikiran yang dihasilkan oleh} para ulama kontemporer seperti Arkoun tersebut merupakan sebuah upaya untuk mewujudkan paradigma baru dalam memaknai agama dan ajarannya. Agar umat Islam bisa hidup berkembang di dunia kontemporer secara "nyaman dan damai" tanpa merasa dihegemoni pihak lain, maka perlu adanya perubahan pola pikir (habits of mind) dengan melakukan perubahan paradigma (shifting paradigm) 
terhadap epistemologi keilmuan Islam yakni dari epistemologi keislaman normatif-tekstual-bayani yang berakibat pada sulitnya mengadopsi dan mengelaborasi wawasan dan temuan baru di bidang sains dan perkembangan baru di bidang budaya, ke epistemologi keilmuan Islam kontemporer yang bercorak intuitifspiritual-irfani (secara aksiologis) yang banyak berkaitan dengan dimensi etika bagi pengembangan sains dan budaya, maupun yang bercorak empiris-historis-burhani (secara epistemologis) yang berdampak pada adanya temuan baru (al-qirā'ah al-muntijah) di bidang sains dan perkembangan sosial budaya. $^{20}$

Epistemologi keilmuan Islam klasik yang terkesan ideologis dan cenderung menghambat kemajuan temuan sains dan perkembangan sosial budaya perlu di-review ulang sebagaimana ditawarkan oleh pemikir-pemikir Muslim kontemporer di atas. Pemahaman tentang ijtihad seperti yang dikemukakan Mohammad Iqbal sebagai the principle of movement dapat dijadikan

\footnotetext{
${ }^{20}$ Ibid.
}

acuan filosofis bagi upaya pergeseran paradigmatik ini.

\section{Perubahan Paradigma dalam Studi Islam}

1. Islam dan Isu-Isu

Kontemporer: Demokrasi dan

Hak Asasi Manusia

Pertanyaan yang paling sering muncul di masa modern sekarang ini adalah apakah Islam sesuai dengan nilai-nilai kemodernan. Tantangan Islam dalam menghadapi nilai-nilai modernitas akan terus menjadi sorotan dunia, karena banyak umat Islam yang memang menolak nilainilai yang terkandung dalam modernitas tersebut. Di masa kontemporer sekarang ini, istilah demokrasi bagi banyak orang dianggap sebagai kata yang mengimplikasikan nilai-nilai perjuangan untuk kebebasan dan jalan hidup yang lebih baik. Demokrasi bukan hanya merupakan metode kekuasaan mayoritas melalui partisipasi rakyat dan kompetisi yang bebas, tetapi juga mengandung nilainilai universal, khususnya nilai-nilai persamaan, kebebasan dan pluralisme, walaupun konsep-konsep operasionalnya bervariasi menurut kondisi budaya negara tertentu. Nilai 
demokrasi juga berkaitan dengan eksistensi dan pemeliharaan hak asasi manusia $(\mathrm{HAM}){ }^{21}$ Konsep HAM dalam studi Islam sudah menjadi suatu keharusan di masa sekarang, terutama dalam kaitannya dengan kajian hukum di seluruh dunia Islam, misalnya di Indonesia $^{22}$ dan Malaysia. $^{23}$

Pembahasan yang mendalam tentang isu-isu kontemporer seperti Hak Asasi Manusia, kesetaraan gender, pluralisme agama, hubungan dan hukum Internasional yang menggunakan standar PBB, mengagetkan para ilmuan Islam yang masih menggunakan perspektif metodologi keilmuan lama. Corak pendekatan kritis dalam studi agama (Islam) belum begitu dikenal dan tidak popular di kalangan masyarakat Muslim. Ada keyakinan kuat (belief) di kalangan umat Islam bahwa pelaksanaan ajaran agama di

21 Bani Syarif Maula, "Islam dan Modernitas: Pandangan Muslim terhadap Perkembangan Sosial, Politik dan Sains", Fikrah: Jurnal Ilmu Aqidah dan Studi Keagamaan, Vol. 5, No. 2, 2017, hlm. 331354.

${ }^{22}$ Moh. Dahlan, "Nilai-Nilai Kemanusiaan dalam Legislasi Hukum Islam di Indonesia", Al-Manahij: Jurnal Kajian Hukum Islam, Vol. 10, No. 2, 2016, hlm. 217-234.

23 Ahmad Rofi'i, "Globalisasi HAM dan Hukum Keluarga Islam di Malaysia”, $A l$ Manahij: Jurnal Kajian Hukum Islam, Vol. 9, No. 2, 2015, hlm. 303-318. masyarakat tidak perlu dipertanyakan ulang, tidak perlu ditinjau ulang, tidak perlu diteliti, tidak perlu diamati, yang semua itu berarti bahwa ajaran agama Islam tidak boleh dikritik. Bahkan lebih dari itu, upaya penafsiran kembali ajaran agama dianggap sebagai propaganda Barat yang hendak menghancurkan Islam. ${ }^{24}$

Pandangan-pandangan negatif terhadap upaya penafsiran ulang ajaran agama Islam berakar pada metode pemahaman agama (habits of mind) yang bisa ditandai dengan beberapa karakteristik. Pertama, skripturalisme, yaitu keyakinan harfiah terhadap kitab suci yang merupakan firman Tuhan dan dianggap tidak mengandung kesalahan. Kedua, penolakan terhadap hermeneutika, di mana teks al-Qur'an harus dipahami secara literal sebagaimana bunyinya. Nalar atau akal dipandang tidak mampu memberikan interpretasi yang tepat terhadap teks, bahkan terhadap teksteks yang satu sama lain bertentangan sekalipun. Ketiga, penolakan terhadap pluralisme dan relativisme yang dianggap merongrong kesucian teks. Keempat, penolakan terhadap

\footnotetext{
${ }^{24}$ Ibid.
} 
perkembangan historis dan sosiologis yang dianggap membawa manusia semakin jauh melenceng dari doktrin literal kitab suci. Ayat-ayat al-Qur'an dan hadis diberlakukan dengan melepaskannya dari konteks dan kondisi historis saat ia diwahyukan.

Upaya menyesuaikan ajaran Islam dengan isu-isu kontemporer jelas harus dengan cara melakukan reinterpretasi ajaran Islam (yang di dalam khazanah keilmuan Islam sendiri telah dikenal dengan istilah tajdìd dan ijtihād). Selain itu, umat Islam juga harus menyadari bahwa mereka hidup bersama pemeluk agama lain dan budaya yang berbedabeda, sehingga sikap ekslusif juga harus dilawan melalui dunia pendidikan yang menekankan aspekaspek kesadaran multikultural. Demokrasi dan HAM merupakan realitas sejarah yang harus diterima oleh umat Islam, sebagaimana umat Islam pernah menerima konsepkonsep lain di masa lalu sebagai bagian dari realitas sejarah.

\section{Gerakan Global Salafisme}

Akhir-akhir ini salafisme menjadi topik perbincangan yang menarik baik di dunia Muslim maupun di dunia luar. Salafisme telah berkembang begitu cepat, bahkan ia menjadi gerakan keagamaan yang berkembang paling signifikan di dunia di masa kontemporer ini. Secara umum, media massa atau buku-buku akademis belakangan ini menggunakan istilah salafisme untuk merujuk pada sebuah gerakan Islam yang intoleran, rigid, bahkan reaksioner; dan salafisme telah menjadi aliran pemikiran atau kelompok yang anti-modernitas dan pembaruan. Muhammad Âbid alJâbirî menggunakan istilah salafisme ini untuk menunjuk pada setiap gerakan yang menjadikan al-Qur'an dan hadis sebagai sistematika pemikirannya. $^{25}$

Gerakan salafi mengikuti pemikiran Ahmad bin Hanbal (789855 M), Ibnu Taimiyah (1263-1328 M), serta Muhammad bin Abdul Wahhab (1703-1792 M), yang orientasi pemikirannya bersifat literal dan tekstual. Karakter gerakan salafi ini adalah menganggap sebuah teks sudah sedemikian "terang benderang". Teks suci dianggap bisa

25 Noorhaidi Hasan, "Ambivalent Doctrines and Conflicts in the Salafi Movement in Indonesia", dalam Roel Meijer (ed.), Global Salafism: Islam's New Religious Movements (London: Hurst \& Company, 2009), hlm. 169. 
Jurnal Yaqzhan : Analisis Filsafat, Agama dan Kemanusiaan|

Vol 5, No 1, Juni 2019

berbicara sendiri tanpa memerlukan seorang penafsir. Takwil atau penafsiran alegoris dipandang dengan penuh kecurigaan. Kaum salafi menghendaki kembalinya pola kehidupan Muslim generasi pertama. Mereka percaya pada penafsiran alQur'an yang tegas dan harfiah, dan hal itu mempunyai daya tarik yang besar terhadap generasi muda seluruh dunia. $^{26}$

Peneliti Norwegia, Thomas Hegghammer, menyatakan di masa perubahan-perubahan besar dan pilihan besar yang terus-menerus dan dengan kepastian-kepastiannya yang sederhana, salafisme menimbulkan keyakinan kuat di kalangan generasi muda yang sedang mencari-cari format beragama secara ideal, baik di dunia Arab maupun di negeri Barat dan berbagai belahan dunia lainnya. Tidak hanya itu, dengan klaimnya sebagai al-firqah al-nājīyah, salafisme menjadi magnet bagi kelompok orang-orang tertindas, kaum migran yang didiskriminasikan, serta orang-orang yang termarjinalkan

26 Iffah Muzammil, "Global Salafisme antara Gerakan dan Kekerasan", Teosofi: Jurnal Tasawuf dan Pemikiran Islam, Vol. 3, No. 1, Juni 2013, hlm. 211234. secara politik, karena merasa memiliki akses kepada kebenaran. ${ }^{27}$

Salah satu doktrin salafisme (terutama salafi jihadi) adalah alwalā' wa al-barrā'. Doktrin ini mengatur hubungan antara komunitas mukmin dan non-mukmin. Berdasarkan doktrin ini, seorang mukmin harus menjauhkan diri dari non-mukmin, yang tujuannya adalah untuk memotong loyalitas antara warga Muslim dan non-Muslim. Doktrin ini juga mengajarkan bahwa seorang Muslim yang tinggal di wilayah non-Muslim harus berpindah ke wilayah Islam. Seorang mukmin sejati hanya bisa mengungkapkan keyakinan dan ketulusan imannya dengan menunjukkan permusuhan terbuka terhadap kaum "musyrik" serta melancarkan jihad melawan mereka. Selain itu, doktrin takfîr juga menjadi salah satu kekhasan kelompok salafi jihadi. Berdasarkan doktrin tersebut, kaum Muslim yang berfikiran lain, dianggap kafir dan murtad. Doktrin lainnya adalah alamr bi al-ma'rūf wa al-nahy 'an almunkar. Doktrin tersebut digunakan oleh kelompok ini untuk memberdayakan para pengikutnya

\section{${ }^{27}$ Ibid.}


agar aktif berdakwah, bahkan lebih kuat dengan mengambil bagian dalam jihad. Doktrin ini juga digunakan sebagai alat untuk menegakkan moralitas publik dan alat politik untuk melawan oposisi sekuler. ${ }^{28}$

Munculnya gerakan salafisme global telah menjadi bahan renungan bersama bagi para pemikir Islam kontemporer. Apa yang perlu dilakukan agar umat Islam dapat menjadi bagian dari pembangunan dunia yang damai dan tenteram dalam kebersamaan. Tuduhan terhadap Islam yang tidak membawa misi perdamaian tetapi justru misi kekerasan sulit untuk ditolak manakala kita menyaksikan bahwa agama seringkali digunakan sebagai landasan ideologis dan pembenaran simbolis bagi tindak kekerasan yang dilakukan sebagian umatnya. Kondisi ini telah menjadi titik tolak bagi para pemikir Muslim kontemporer untuk dapat mengembalikan ajaran Islam ke dalam misi utamanya, yaitu perdamaian, keseimbangan dan

28 Joas Wagemakers, "The Transformation of a Radical Concept: alwala' wa-l-bara' in the Ideology of Abu Muhammad al-Maqdisi", dalam Roel Meijer (ed.), Global Salafism: Islam's New Religious Movements (London: Hurst \& Company, 2009), hlm. 81. keadilan, serta ketentraman dalam kehidupan yang beragam dan plural.

\section{Al-Qira'ah al-Mutakarrirah}

(Pembacaan yang Berulang)

Isu-isu agama banyak bermunculan dewasa ini yang jika diamati ujungnya bermuara pada "pertikaian idiologis" yang ingin memberikan maksud dan tujuan sepihak terhadap perumusan dan pengambilan keputusan agama (fatwa-fatwa) yang terkait dengan isuisu masyarakat kontemporer. Sebut saja misalnya fatwa tentang kesesatan pluralisme agama dan fatwa keharaman ucapan selamat Natal yang hampir setiap tahun selalu dimunculkan. Kedua fatwa itu dianggap penting sebagai benteng umat Islam bagi upaya pendangkalan akidah.

Kelompok Muslim yang selalu merasa bahwa Islam berada dalam ancaman, kaum Muslim selalu dibayang-bayangi ideologi konfliktual, dan bahkan ada upayaupaya dari pihak di luar Islam, khususnya dunia Barat, yang akan menghancurkan Islam, merupakan kondisi yang menyebabkan banyaknya kaum Muslim yang mempertahankan jati diri ke-islam- 
annya melalui pengamalan tafsirtafsir ajaran agama yang hanya sesuai di masa lalu. Pembaharuan dianggap sebagai bentuk inovasi yang besifat bid'ah atau heresy.

Produk pemikiran Islam masa lalu selalu dipraktekkan dan dianggap sebagai suatu kebenaran. Nasr Hamid Abu Zayd, misalnya, membuktikan bahwa aktifitas akademik yang dikerjakan para sarjana Muslim adalah pembacaan repetitive (alqirā'ah al-mutakarrirah), Abu Zayd mengkritisinya dengan istilah pembacaan ideologis tendensius (alqirā'ah al-mughridah almulawwanah) dan pembacaan yang ahistoris (al-qirā'ah al-lā-tārīkhiyyah). Sebagai tawarannya Abu Zayd mengusulkan pembacaan produktifhermeneutis (al-qirā'ah almuntijah). ${ }^{29}$

Oleh karena itu, khazanah keilmuan Islam sebagaimana yang kita kenal sekarang ini tidaklah cukup memadai untuk menghadapi persoalan dan tantangan-tantangan baru era modernitas dan pascamodernitas. Untuk keluar dari paradigma keilmuan agama Islam yang lama ke yang baru perlu upaya-

29 M. Amin Abdullah, "Mempertautkan Ulum al-Din". upaya baru yang dapat mengawinkan, memperkaya, mempertautkan khazanah intelektual lama (al-turāis) dengan khazanah intelektual baru (alhadāsah; bahkan mā ba'da alḩadāsah) agar generasi baru yang hidup pada era global sekarang dan lebih-lebih yang akan datang tidak gamang menghadapi modernitas dan pasca-modernitas. ${ }^{30}$

\section{Agenda Studi Islam di Masa}

\section{Sekarang}

\section{Kontinuitas dan Perubahan (Continuity and Change)}

Dalam khazanah pemikiran keagamaan Islam klasik, khususnya dalam pendekatan Uṣūl al-Fiqh, dikenal istilah al-siawābit (hal-hal yang diyakini atau dianggap "tetap", tidak berubah) dan al-mutaghayyirāt (hal-hal yang diyakini atau dianggap "berubah-ubah", tidak tetap). Yang pertama biasanya dikategorikan sebagai pokok ajaran (uṣūl) dan yang kedua adalah cabang ( $f u r \bar{u}$ '). Dalam epistemologi pemikiran Islam kontemporer, kedua konsep tersebut dimaknai secara lebih luas sebagai upaya pembacaan ulang atas ajaran agama, karena memang tidak dapat

\footnotetext{
${ }^{30}$ Ibid.
} 
dipungkiri bahwa ajaran Islam tidak berada dalam ruang hampa. Nass-nass atau wahyu yang diinterpretasi akan selalu berinteraksi dengan lingkungannya, yang dalam hal ini ada tiga pihak, yaitu: pengarang, pembaca dan audiensnya. Ada rentang waktu-dulu, kini, mendatang — di hadapan ketiga pihak tersebut. Inilah yang disebut dengan lingkaran hermeneutis (hermeneutical circle); suatu perubahan terus menerus dalam melakukan interpretasi terhadap kitab suci (alnuṣūṣ al-mutanāhiyah) yang dipandu oleh perubahan-perubaan berkesinambungan dalam realitas masa kini, baik individu maupun masyarakat. Dalam konteks yang terus berubah ini, kebutuhan akan cara pembacaan baru atas teks-teks dan realitas itu menjadi tak terelakkan. Dengan memahami lingkaran hermeneutis semacam ini, Muslim tidak perlu mengulang-ulang tradisi lama (turas) yang memang sudah usang untuk kepentingan kekinian dan kedisinian, tetapi juga bukan berarti menerima apa adanya modernitas (hadāsah). Kewajiban muslim adalah melakukan pembacaan atas teks-teks wahyu dan realitas itu secara produktif (al-qirā'ah almuntijah) bukan pembacaan repetisi hasil interpretasi masa lalu (alqirā'ah al-mutakarrirah).

Dengan memperhatikan tuntutan-tuntutan perkembangan, kontinuitas dan perubahan (continuity and change) dalam realitas kontemporer, perlu diupayakan perubahan paradigma. Perubahan paradigma tidak berarti semua tradisi ditinggalkan, tetapi patut dipahami sebagai upaya modifikasi tradisi pemikiran Islam dalam ukuran tertentu sesuai dengan problem sosial yang ada; dan atau merubah secara total tradisi dengan sesuatu yang sama sekali baru. Yang pertama dalam rangka menjaga kontinuitas dalam pemikiran keislaman atau melakukan pengembangan, sementara yang kedua adalah untuk memproduksi pemikiran keislaman yang sama sekali baru.

2. Al-Qirā'ah al-Muntijah

\section{(Pembacaan yang Produktif)}

Agar umat Islam tidak tertinggal oleh gerbong peradaban dunia global sekarang ini, perlu dilakukan upaya-upaya yang sistematis dalam hal pembaharuan pemikiran dan rekonsturksi 
Jurnal Yaqzhan : Analisis Filsafat, Agama dan Kemanusiaan|

Vol 5, No 1, Juni 2019

epistemologi studi Islam dalam al-muntijah). Al-qirā'ah al-muntijah rangka penafsiran ulang (reinterpretasi) ajaran agama. Banyak ulama-ulama kontemporer yang sudah melakukan upaya pembacaan ulang atas teks-teks ajaran agama (alQur'an dan Sunnah) tersebut. Nasr Hamid Abu Zayd, misalnya, mencoba menawarkan teori teks dalam hermeneutik dengan teorinya yang menyatakan bahwa al-Qur'an betapapun mempunyai nilai sakralitas karena merupakan wahyu Allah, tetapi ia merupakan teks yang juga dapat dikaji secara kritis seperti teksteks lainnya. Sementara itu, Arkoun juga mencoba menawarkan metode baru bagaimana mengkaji al-Qur'an secara lebih kritis. Menurutnya alQur'an merupakan teks yang selalu terbuka (korpus terbuka) untuk ditafsirkan, sehingga jangan sampai ada taqdīs al-afkār al-dìniyyah atau pensakralan pemikiran keagamaan, termasuk dalam penafsiran al-Qur'an.

Dengan demikian, apa yang sudah dilakukan oleh para ulama kontemporer seperti Abu Zayd dan Arkoun merupakan suatu upaya melakukan reinterpretasi al-Qur'an melalui pembacaan atas teks-teks wahyu secara produktif (al-qirä'ah

merupakan cara pembacaan teks-teks ajaran Islam dengan mempertimbangkan pemahaman seseorang terhadap perubahanperubahan sejarah, sehingga pembacaan yang produktif akan selalu mempertimbangkan aspek historisitas (tärikhiyyah), dan yang dimaksud dengan historisitas tersebut adalah adanya dimensi perubahan (sosial, politik, ekonomi, budaya) dalam sebuah masyarakat.

\section{Perlunya Kesadaran Muslim sebagai Bagian dari World Citizenship}

Perubahan yang sangat pesat di abad ke-21 ini disebabkan karena adanya perkembangan ilmu pengetahuan, tatanan sosial-politik dan sosial-ekonomi, hukum, tata kota, lingkungan hidup dan sebagainya, dalam rangka mengatur dan memperbaiki kualitas kehidupan manusia. Perubahan yang sangat pesat tersebut, menurut Abdullah Saeed, antara lain terkait dengan globalisasi, migrasi penduduk, kemajuan sains dan teknologi, pendidikan dan tingkat literasi. Di atas itu semua adalah bertambahnya 
pemahaman dan kesadaran tentang pentingnya harkat dan martabat manusia (human dignity), perjumpaan yang lebih dekat antar-umat beragama (greater inter-faith interaction), munculnya konsep negara-bangsa yang berdampak pada kesetaraan dan perlakuan yang sama kepada semua warga negara (equal citizenship), belum lagi kesetaraan gender dan sebagainya. Perubahan sosial yang dahsyat tersebut berdampak luar biasa dan mengubah pola berpikir dan pandangan keagamaan (religious worldview) baik di lingkungan umat Islam maupun umat beragama yang lain. $^{31}$

Dengan demikian, sangat jelas bahwa perubahan sosial yang cepat di masa sekarang merupakan implikasi dan konsekwensi dari globalisasi dunia yang diakibatkan oleh kemajuan ilmu penetahuan dan teknologi. Globalisasi telah menyebabkan umat Islam yang hidup saat sekarang ini di manapun mereka berada sebagai bagian dari warga dunia (world citizenship), selain sebagai warga lokal/nasional, yang

31 M. Amin Abdullah, "Bangunan Baru Epistemologi Keilmuan Studi Islam dalam Merespon Globalisasi”, Asy-Syir'ah: Jurnal Ilmu Syari'ah dan Hukum, Vol. 46, No. 2, Juli-Desember 2012, hlm. 315-368. tidak dapat lepas dari pengaruh dan bahkan pengamatan global warga dunia yang lain. Perubahan sosial yang begitu cepat tersebut berdampak sangat luas terhadap pandangan kemanuasiaan (humanity) dan pandangan keagamaan (religious worldview) yang berbeda di lingkungan umat Islam dibanding masa-masa sebelumnya.

Masyarakat Muslim kontemporer di manapun berada, sekarang terikat dengan kesepakatan dan perjanjian-perjanjian internasional, khususnya setelah terbentuknya badan dunia seperti Persyarikatan Bangsa-Bangsa (PBB) dengan berbagai urusan mulai dari urusan kesehatan dunia (WHO), pangan-pertanian (FAO), pendidikan dan kebudayaan (UNESCO), perdagangan (WTO), keamanan (Dewan Keamanan PBB), perburuhan (ILO), perubahan iklim (climate change) dunia dan masih banyak yang lain. Dengan demikian, umat Islam harus memiliki pemahaman dan kesadaran tentang pentingnya harkat dan martabat manusia (human dignity), dan perlu lebih sering melakukan perjumpaan yang lebih 
Jurnal Yaqzhan : Analisis Filsafat, Agama dan Kemanusiaan|

Vol 5, No 1, Juni 2019

dekat antar-umat beragama (greater inter-faith interaction). ${ }^{32}$

Nilai-nilai universal ditetapkan berdasarkan kesepakan-kesepakatan internasional melalui badan-badan PBB. Munculnya konsep demokrasi dan Hak Asasi Manusia (HAM) merupakan sekian di antara nilai-nilai universal tersebut, yang berdampak pada tuntutan akan kesetaraan dan perlakuan yang sama kepada semua warga negara (equal citizenship), belum lagi adanya tuntutan kebebasan beragama, kebebasan berkespresi, kesetaraan gender dan isu-isu HAM lainnya. Konstitusi dan aturan perundang-undangan di negaranegara Muslim pun selalu dinilai dengan standar internasional tersebut. Minimnya perlindungan HAM dan masih diberlakukannya pelaksanaan hukuman-hukuman yang kejam (yang terdapat dalam al-fiqh al-jināya $\bar{t}$ ) oleh negara-negara Muslim selalu mendapat perhatian dari dunia internasional karena dianggap tidak sesuai dengan nilai-nilai universal tersebut. Karena itulah, umat Islam harus dapat berkomunikasi secara global-universal disertai dengan adaptasi terhadap nilai-nilai universal yang telah disepakati dunia internasional. $^{33}$

\section{SIMPULAN}

Memperbincangkan studi Islam merupakan suatu hal yang selalu menarik dan kerapkali mengundang banyak perdebatan. Tidak hanya menyangkut persoalanpersoalan teoretis, tetapi juga menyangkut ranah aplikatif dalam kehidupan sosial keagamaan. Persoalan studi agama, khususnya Islam, selalu mengalami dinamika sesuai dengan perkembangan ilmu pengetahuan. Karena itulah, makalah ini menyimpulkan bahwa pendekatan apapun yang digunakan untuk melakukan studi Islam, tidak dapat mendorong seseorang untuk cenderung mengukuhkan dan melahirkan truth claim terhadap pendekatannya dan menafikan yang lainnya. Terjadinya ketegangan antara berbagai pendekatan dalam studi Islam dapat memunculkan klaimklaim kebenaran dan asumsi-asumsi dasar yang nonfalsifiable, tanpa mengindahkan dimensi falsifiable yang melekat dalam kubu masingmasing. Selain itu, paradigma baru 
yang sesuai dengan perkembangan

ilmu pengetahuan, khususnya ilmuilmu sosial, perlu mendapat tempat agar dapat menawarkan pandangan baru dalam mengkaji agama yang lebih terbuka, mampu membuka dialog dan kerjasama, transparan, dapat dipertanggungjawabkan secara publik dan berpandangan ke depan.

\section{DAFTAR PUSTAKA}

Abdullah, M. A. (2001). Kata Pengantar, dalam Richard C. Martin (Ed), Kajian Islam dalam Studi Agama: Terjemahan. Zakiyuddin Baidhawy. Surakarta: Muhammadiyah University Press.

Abdullah, M. A. (2003). New Horizon of Islamic Studies through Socio-Cultural Hermeneutics, Al-Jami'ah: Journal of Islamic Studies, Vol. 41, No. 1, 2003: 1-24.

Abdullah, M. A. (2008). Pengantar, dalam Jasser Auda, Membumikan Hukum Islam Melalui Maqasid Syariah, terj. Rosidin dan 'Ali 'Abd elMun'im. Bandung: Mizan.

Abdullah, M. A. (2012). Bangunan Baru Epistemologi Keilmuan Studi Islam dalam Merespon Globalisasi, Asy-Syir'ah: Jurnal Ilmu Syari'ah dan Hukum, Vol. 46, No. 2, JuliDesember 2012: 315-368.

Abdullah, M. A. (2017). Islamic Studies in Higher Education in Indonesia,

Al-Jami'ah:
Journal of Islamic Studies, Vol. 55, No. 2, 2017: 391-426. Abdullah, M. A. (2014). Religion, Science and Culture: An Integrated, Interconnected Paradigm of Science, $\mathrm{Al}$ Jami'ah: Journal of Islamic Studies, Vol. 52, No. 1, 2014: 175-203.

Dahlan, M. (2016). Nilai-Nilai Kemanusiaan dalam Legislasi Hukum Islam di Indonesia, $A l$ Manahij: Jurnal Kajian Hukum Islam, Vol. 10, No. 2, 2016: 217-234.

Ferber, M. P. (2006). Critical Realism and Religion: Objectivity and the Insider/Outsider Problem, Annals of the Association of American Geographers, Vol. 96, No. 1, Maret 2006: 176181.

Hasan, N. (2009). Ambivalent Doctrines and Conflicts in the Salafi Movement in Indonesia, dalam Roel Meijer (ed.), Global Salafism: Islam's New Religious Movements. London: Hurst \& Company.

Knott, K. (2005). Insider/Outsider Perspectives, dalam John R. Hinnells (ed.), The Routledge Companion to the Study of Religion. New York: Routledge.

Maula, B. S. (2017). Islam dan Modernitas: Pandangan Muslim terhadap Perkembangan Sosial, Politik dan Sains, Fikrah: Jurnal Ilmu Aqidah dan Studi Keagamaan, Vol. 5, No. 2, 2017: 331-354.

Meijer, R. (2009). Global Salafism: Islam's New Religious Movements. London: Hurst \& Company.

Mighfar, S. (2012). Studi Agama Perspektif Insider-Outsider, 
Jurnal Lisan al-Hal, Vol. 4, No. 2, Desember 2012: 303329.

Muzammil, I. (2013). Global Salafisme antara Gerakan dan Kekerasan. Teosofi: Jurnal Tasawuf dan Pemikiran Islam, Vol. 3, No. 1, Juni 2013: 211234.

Rauf, M. A. (2001). Outsiders' Interpretation of Islam dalam Richard C. Martin (ed.) Approaches to Islam in Religious Studies. Oxford: Oneworld Publications, 2001.

Rofi'i, A. (2015). Globalisasi HAM dan Hukum Keluarga Islam di Malaysia. Al-Manahij: Jurnal Kajian Hukum Islam, Vol. 9, No. 2, 2015: 303-318.

Ryba, T. (2006). Phenomenology of Religion, dalam Robert A. Segal, The Blackwell Companion to the Study of Religion. USA: Blackwell Publishing.

Saleh, S. Z. (2010). Perspektif Insider-Outsider dalam Studi Agama: Membaca Gagasan Kim Knott”. Jurnal Tsaqafah, Vol. 6, No. 2, Oktober 2010: 271-290.

Segal, R. A. (2006). Introduction, dalam Robert A. Segal, The Blackwell Companion to the Study of Religion. USA: Blackwell Publishing.

— (2006). The Blackwell Companion to the Study of Religion. USA: Blackwell Publishing.

Smith, W. C. (1959). Comparative Religion: Whither and Why?, dalam Mircea Eliade and J. M. Kitagawa (eds.), The History of Religions: Essays in Methodology. Chicago: The University of Chicago.
Wagemakers, J. (2009). The Transformation of a Radical Concept: al-wala' wa-l-bara' in the Ideology of Abu Muhammad al-Maqdisi, dalam Roel Meijer (ed.), Global Salafism: Islam's New Religious Movements. London: Hurst \& Company. 